\title{
Editorial
}

\section{Mudança dos critérios Qualis!}

A Associação Médica Brasileira (AMB) preocupada com o futuro das publicações científicas brasileiras, depois da divulgação dos novos critérios QUALIS da CAPES, vem desde agosto de 2009 organizando uma série de encontros em sua sede em São Paulo, em parceria com a Associação Brasileira de Editores Científicos - ABEC Brasil. Os encontros resultaram em um editorial denominado Classificação dos periódicos no sistema QUALIS da CAPES - a mudança dos critérios é URGENTE! Este foi assinado por 62 editores de revistas científicas e publicado na íntegra em todas elas e em outras inúmeras principalmente na área da saúde, evidenciando uma sensibilização e um envolvimento cada vez maior dos periódicos nacionais em discutir problemas comuns. ${ }^{1}$

A comunidade científica continua preocupada com as perspectivas, os rumos e o futuro dos periódicos brasileiros. ${ }^{2,3}$ Assim, na reunião de 18 de março os editores presentes puderam avaliar as repercussões do primeiro Editorial que serviu de base para discussões em eventos e reuniões científicas pelo país. Esta última reunião contou com a participação da Dra. Lilian Caló, Coordenadora de Comunicação Científica e Avaliação do SciELO, que apresentou estudo comparativo dos periódicos brasileiros na referida base classificados por dois critérios: o primeiro conforme o fator de impacto ISI/JCR, que usa somente as revistas indexadas na base Thomson Reuters, e segundo um índice composto pela somatória simples dos fatores de impacto ISI/JCR e do SciELO. O fator de impacto SciELO, que também considera citações de todos os periódicos da sua base, modifica significativamente o número de citações obtidas e, consequentemente, eleva o fator de impacto dos periódicos brasileiros. Este fato ficou mais evidente com a demonstração apresentada pela Dra. Caló do ganho percentual obtido pelos periódicos com a adoção do índice composto. Fica claro que associar outros índices, criar equivalências ou alternativas diversas podem favorecer a qualificação das revistas nacionais, melhorando sua visibilidade e favorecendo a indexação internacional. Também deve se considerar que os pesquisadores nacionais estão preferindo publicar seus conteúdos em revistas estrangeiras ao invés de fazê-los em revistas nacionais. Esta escolha melhora a qualificação do Programa de Pós-graduação ao qual estão inseridos, conquista fator de impacto mais elevado e aumenta o índice $\mathrm{H}$; tudo isso única e exclusivamente por conta dos novos critérios adotados pela CAPES. A busca de maior visibilidade e qualidade da produção nacional não deve ser avaliada somente pelos artigos, mas também por maior qualificação de nossos periódicos para que eles sejam reconhecidos internacionalmente.

Considerando que para atual avaliação trienal da CAPES os critérios já estão definidos, os editores reunidos decidiram elaborar um novo editorial contendo uma lista de sugestões a ser encaminhada para a coordenação da CAPES para a próxima avaliação. A lista de sugestões que complementam a do primeiro editorial é a seguinte:

- revisão dos critérios usados pela CAPES para classificação dos periódicos, sugerindo que seja adotado o fator de impacto composto pela somatória dos fatores de impacto ISI/JCR e SciELO;

- obtenção de um assento para a ABEC Brasil (Associação Brasileira dos Editores Científicos) no Conselho Técnico Científico da CAPES, para que os editores possam ser ouvidos no processo;

- solicitação da "Bolsa do Editor" junto ao CNPq para auxílio à editoração científica destinada a editores de revistas brasileiras que recebem apoio da referida agência de fomento. Este recurso tem por objetivo aprimorar a qualidade das revistas obtendo maior dedicação de seus editores às funções editoriais.

Além disto, os editores reunidos decidiram obter apoio da Academia Brasileira de Ciências, da FINEP e do Deputado Eleuses Vieira de Paiva para suas reivindicações e sugestões. Num 
segundo momento os editores solicitarão ao $\mathrm{CNPq}$ detalhamento dos resultados e dos critérios adotados para distribuição dos recursos dos Editais para Auxílio à Editoração (AED). Com estas informações os editores pretendem construir um banco de dados com informações sobre orçamentos anuais dos periódicos brasileiros que será útil para análise comparativa e cooperação mútua. A divulgação dos dois editoriais e sua discussão continuam sendo nossa meta em buscar o reconhecimento que os periódicos nacionais necessitam e merecem.

\section{Referências}

1. Classificação dos Periódicos no sistema QUALIS da CAPES - A mudança dos critérios é urgente! Rev Assoc Med Bras. 2010;56(2):127-43.

2. de Lucena AF, Tibúrcio RV. Qualis periódicos: visão do acadêmico na graduação médica. Rev Assoc Med Bras. 2009;55(3):247-8.

3. Rocha-e-Silva Mauricio. O novo Qualis, ou a tragédia anunciada. Clinics. 2009 Jan;64(1):1-4.

Assinam este Editorial:

\begin{tabular}{|c|c|}
\hline Adagmar Andriolo & Jornal Brasileiro de Patologia e Medicina Laboratorial \\
\hline Alfredo José Afonso Barbosa & Jornal Brasileiro de Patologia e Medicina Laboratorial \\
\hline Arnaldo José Hernandez & Revista Brasileira de Medicina do Esporte \\
\hline Aroldo F. Camargos & Revista Femina \\
\hline Benedito Barraviera & Journal of Venomous Animals and Toxins including Tropical Diseases \\
\hline Bogdana Victoria Kadunc & Surgical \& Cosmetic Dermatology da Soc. Brasileira de Dermatologia \\
\hline Bruno Caramelli & Revista da Associação Médica Brasileira \\
\hline Carlos Brites & Brazilian Journal of Infectious Diseases \\
\hline Dejair Caitano do Nascimento & Hansenologia Internationalis \\
\hline Domingo M. Braile & Revista Brasileira de Cirurgia Cardiovascular \\
\hline Dov Charles Goldenberg & Revista Brasileira de Cirurgia Plástica \\
\hline Edmund Chada Baracat & Revista da Associação Médica Brasileira \\
\hline Edson Marchiori & Revista Radiologia Brasileira \\
\hline Eduardo de Paula Vieira & Revista Brasileira de Coloproctologia \\
\hline Eros Antônio de Almeida & Revista da Sociedade Brasileira de Clínica Médica \\
\hline Flávia Machado & Revista Brasileira de Terapia Intensiva \\
\hline Geraldo Pereira Jotz & Revista Brasileira de Cirurgia Cabeça e Pescoço \\
\hline Gianna Mastroianni Kirsztajn & Jornal Brasileiro de Nefrologia \\
\hline Gilberto Camanho & Revista Brasileira de Ortopedia \\
\hline Gustavo Gusso & Medicina Família e Comunidade \\
\hline Ivomar Gomes Duarte & Revista de Administração em Saúde \\
\hline Izelda Maria Carvalho Costa & Anais Brasileiros de Dermatologia \\
\hline João Ferreira de Mello Júnior & Brazilian Journal of Otorhinolaryngology \\
\hline Joel Faintuch & Revista Brasileira de Nutrição Clínica \\
\hline José Antônio Baddini Martinez & Jornal Brasileiro de Pneumologia \\
\hline José Antonio Livramento & Revista Arquivos de Neuropsiquiatria \\
\hline José Eduardo Ferreira Manso & Revista do Colégio Brasileiro de Cirurgiões \\
\hline José Eulálio Cabral Filho & Revista Brasileira de Saúde Materno Infantil \\
\hline José Heverardo da Costa Montal & Revista da Associação Brasileira de Medicina de Tráfego \\
\hline
\end{tabular}




\begin{tabular}{|c|c|}
\hline José Luiz Gomes do Amaral & Revista da Associação Médica Brasileira \\
\hline José Luiz Martins & Archives of Pediatric Surgery \\
\hline Jurandyr Moreira de Andrade & Revista Brasileira de Ginecologia e Obstetrícia \\
\hline Leonardo Cançado Monteiro Savassi & Revista Brasileira de Medicina de Família e Comunidade \\
\hline Luís dos Ramos Machado & Revista Arquivos de Neuropsiquiatria \\
\hline Luiz Felipe P. Moreira & Arquivos Brasileiros de Cardiologia \\
\hline Luiz Henrique Gebrim & Revista Brasileira de Mastologia \\
\hline Marcelo Madeira & Revista Brasileira de Mastologia \\
\hline Marcelo Riberto & Revista Acta Fisiátrica \\
\hline Marcus Bastos & Jornal Brasileiro de Nefrologia \\
\hline Mário Cícero Falcão & Revista Brasileira de Nutrição Clínica \\
\hline Mario J. da Conceição & Revista da Sociedade Brasileira de Anestesiologia \\
\hline Mauricio Rocha e Silva & Revista Clinics \\
\hline Milton Artur Ruiz & Revista Brasileira de Hematologia e Hemoterapia \\
\hline Milton K. Shibata & Arquivos Brasileiros de Neurocirurgia \\
\hline Mittermayer Barreto Santiago & Revista Brasileira de Reumatologia \\
\hline Nelson Adami Andreollo & Arquivos Brasileiros de Cirurgia Digestiva \\
\hline Nivaldo Alonso & Brazilian Journal of Craniomaxilofacial Surgery \\
\hline Osvaldo Malafaia & Arquivos Brasileiros de Cirurgia Digestiva \\
\hline Olavo Pires de Camargo & Acta Ortopedica Brasileira \\
\hline Paulo Manuel Pêgo Fernandes & São Paulo Medical Journal \\
\hline Regina Helena Garcia Martins & Brazilian Journal of Otorhinolaryngology \\
\hline Renato Soibelmann Procianoy & Jornal de Pediatria \\
\hline Ricardo César Pinto Antunes & Revista da Sociedade Brasileira de Cancerologia \\
\hline Ricardo Fuller & Revista Brasileira de Reumatologia \\
\hline Ricardo Guilherme Viebig & Arquivos de Gastroenterologia \\
\hline Ricardo Nitrini & Dementia \& Neuropsychologia \\
\hline Rogério Dedivitis & Revista Brasileira de Cirurgia Cabeça e Pescoço \\
\hline Ronaldo Damião & Urologia Contemporânea \\
\hline Rosângela Monteiro & Revista Brasileira de Cirurgia Cardiovascular \\
\hline Sergio Lianza & Revista Medicina de Reabilitação \\
\hline Sigmar de Mello Rode & Brazilian Oral Research \\
\hline Tarcisio E.P. Barros Filho & Acta Ortopedica Brasileira \\
\hline Wallace Chamon & Arquivos Brasileiros de Oftalmologia \\
\hline Winston Bonetti Yoshida & Jornal Vascular Brasileiro \\
\hline Zuher Handar & Revista Brasileira de Medicina do Trabalho \\
\hline
\end{tabular}




\section{Editorial}

\section{Change the Qualis Criteria!}

Since CAPES published its revised QUALIS criteria, the Brazilian Medical Association (AMB - Associação Médica Brasileira) has been organizing a series of meetings, held at its headquarters in São Paulo, Brazil, starting in August of 2009, in partnership with the Brazilian Association of Scientific Editors (ABEC - Associação Brasileira de Editores Científicos). These meetings led to the publication of an editorial entitled Classification of journals in the QUALIS System of CAPES - URGENT need of changing the criteria! The editorial was signed by 62 editors of scientific journals and published in full in all of them, and in countless others, primarily in the health sciences, demonstrating that Brazil's periodicals are more and more committed to discussing the problems they share in common. ${ }^{1}$

The scientific community remains concerned with the future prospects and direction of Brazilian periodicals. ${ }^{2,3}$ The editors present at the meeting of the 18 of March were therefore in a position to evaluate the repercussions of the first Editorial, which had been discussed at scientific events and meetings all over Brazil. The meeting was attended by Dr. Lilian Caló, who is scientific communication and assessment coordinator for SciELO, and who presented a comparative study of the Brazilian periodicals indexed by SciELO according to two different criteria: the first criterion was the ISI/JCR impact factor, which only uses journals indexed by Thomson Reuters, and the second was an index composed by simple addition of the ISI/JCR and SciELO impact factors. The SciELO impact factor, which includes all the periodicals it indexes, significantly modifies the number of citations and, consequently, raises the Brazilian periodicals' impact factors. Dr. Caló's presentation illustrated this fact more clearly, showing the percentages gained by adopting the composite index. It is clear that combining indexes, or creating equivalencies or several alternatives can promote improved quality among Brazilian journals, raising their visibility and making international indexation more likely. It is also of concern that Brazilian researchers now prefer to publish their work in foreign journals rather than choosing domestic publications. They choose to do this because it improves the ratings of their postgraduate departments, earns them greater impact factors and increases their $\mathrm{H}$ index; all entirely and exclusively a result of the revised criteria adopted by CAPES. Achievement in increasing the visibility and quality of Brazilian scientific production should not be assessed on the basis of articles alone, but should also focus on improving our periodicals to the point at which they are recognized internationally.

Considering that the criteria have already been set for CAPES' current triennial assessment, the assembled editors decided to draft a second editorial containing a list of suggestions for the next assessment, to be sent to the administration at CAPES. The list of suggestions, which supplement those in the first editorial, is as follows:

- that the criteria used by CAPES to classify periodicals be revised, adopting the composite impact factor calculated by summing the ISI/JCR and SciELO impact factors;

- that a seat on the CAPES Scientific Committee be created for ABEC (the Brazilian Association of Scientific Editors) so that editor can be heard within the process;

- that CNPq be requested to create an "Editor's Scholarship" program to support scientific publishing and to be awarded to the editors of journals funded by CNPq. The objective of this project is to improve the quality of these journals by providing their editors with more time to dedicate to their editorial activities.

Additionally, the assembled editors decided to seek support for their criticisms and suggestions from the Brazilian Academy of Sciences (Academia Brasileira de Ciências), from FINEP and from Federal Deputy Eleuses Vieira de Paiva. At a later date the editors will request a detailed breakdown from $\mathrm{CNPq}$ of the criteria adopted for, and the results of, the distribution of the resources allocated through the Publishing Support Grants (Editais para Auxilio à 
Editoração). The editors intend to use these data to construct a database on the annual budgets of Brazilian periodicals, which will be useful for comparative analysis and mutual cooperation. Publication of these two editorials and promotion of discussion is one of our goals in seeking the recognition that Brazilian periodicals both need and deserve.

\section{References}

1. Classificação dos Periódicos no sistema QUALIS da CAPES - A mudança dos critérios é urgente! Rev Assoc Med Bras. 2010;56(2):127-43.

2. de Lucena AF, Tibúrcio RV. Qualis periódicos: visão do acadêmico na graduação médica. Rev Assoc Med Bras. 2009;55(3):247-8.

3. Rocha-e-Silva Mauricio. O novo Qualis, ou a tragédia anunciada. Clinics. 2009 Jan;64(1):1-4.

\section{This editorial is signed by:}

\begin{tabular}{|c|c|}
\hline Adagmar Andriolo & Jornal Brasileiro de Patologia e Medicina Laboratorial \\
\hline Alfredo José Afonso Barbosa & Jornal Brasileiro de Patologia e Medicina Laboratorial \\
\hline Arnaldo José Hernandez & Revista Brasileira de Medicina do Esporte \\
\hline Aroldo F. Camargos & Revista Femina \\
\hline Benedito Barraviera & Journal of Venomous Animals and Toxins including Tropical Diseases \\
\hline Bogdana Victoria Kadunc & Surgical \& Cosmetic Dermatology da Soc. Brasileira de Dermatologia \\
\hline Bruno Caramelli & Revista da Associação Médica Brasileira \\
\hline Carlos Brites & Brazilian Journal of Infectious Diseases \\
\hline Dejair Caitano do Nascimento & Hansenologia Internationalis \\
\hline Domingo M. Braile & Revista Brasileira de Cirurgia Cardiovascular \\
\hline Dov Charles Goldenberg & Revista Brasileira de Cirurgia Plástica \\
\hline Edmund Chada Baracat & Revista da Associação Médica Brasileira \\
\hline Edson Marchiori & Revista Radiologia Brasileira \\
\hline Eduardo de Paula Vieira & Revista Brasileira de Coloproctologia \\
\hline Eros Antônio de Almeida & Revista da Sociedade Brasileira de Clínica Médica \\
\hline Flávia Machado & Revista Brasileira de Terapia Intensiva \\
\hline Geraldo Pereira Jotz & Revista Brasileira de Cirurgia Cabeça e Pescoço \\
\hline Gianna Mastroianni Kirsztajn & Jornal Brasileiro de Nefrologia \\
\hline Gilberto Camanho & Revista Brasileira de Ortopedia \\
\hline Gustavo Gusso & Medicina Família e Comunidade \\
\hline Ivomar Gomes Duarte & Revista de Administração em Saúde \\
\hline Izelda Maria Carvalho Costa & Anais Brasileiros de Dermatologia \\
\hline João Ferreira de Mello Júnior & Brazilian Journal of Otorhinolaryngology \\
\hline Joel Faintuch & Revista Brasileira de Nutrição Clínica \\
\hline José Antônio Baddini Martinez & Jornal Brasileiro de Pneumologia \\
\hline José Antonio Livramento & Revista Arquivos de Neuropsiquiatria \\
\hline José Eduardo Ferreira Manso & Revista do Colégio Brasileiro de Cirurgiões \\
\hline José Eulálio Cabral Filho & Revista Brasileira de Saúde Materno Infantil \\
\hline José Heverardo da Costa Montal & Revista da Associação Brasileira de Medicina de Tráfego \\
\hline
\end{tabular}




\begin{tabular}{|c|c|}
\hline José Luiz Gomes do Amaral & Revista da Associação Médica Brasileira \\
\hline José Luiz Martins & Archives of Pediatric Surgery \\
\hline Jurandyr Moreira de Andrade & Revista Brasileira de Ginecologia e Obstetrícia \\
\hline Leonardo Cançado Monteiro Savassi & Revista Brasileira de Medicina de Família e Comunidade \\
\hline Luís dos Ramos Machado & Revista Arquivos de Neuropsiquiatria \\
\hline Luiz Felipe P. Moreira & Arquivos Brasileiros de Cardiologia \\
\hline Luiz Henrique Gebrim & Revista Brasileira de Mastologia \\
\hline Marcelo Madeira & Revista Brasileira de Mastologia \\
\hline Marcelo Riberto & Revista Acta Fisiátrica \\
\hline Marcus Bastos & Jornal Brasileiro de Nefrologia \\
\hline Mário Cícero Falcão & Revista Brasileira de Nutrição Clínica \\
\hline Mario J. da Conceição & Revista da Sociedade Brasileira de Anestesiologia \\
\hline Mauricio Rocha e Silva & Revista Clinics \\
\hline Milton Artur Ruiz & Revista Brasileira de Hematologia e Hemoterapia \\
\hline Milton K. Shibata & Arquivos Brasileiros de Neurocirurgia \\
\hline Mittermayer Barreto Santiago & Revista Brasileira de Reumatologia \\
\hline Nelson Adami Andreollo & Arquivos Brasileiros de Cirurgia Digestiva \\
\hline Nivaldo Alonso & Brazilian Journal of Craniomaxilofacial Surgery \\
\hline Osvaldo Malafaia & Arquivos Brasileiros de Cirurgia Digestiva \\
\hline Olavo Pires de Camargo & Acta Ortopedica Brasileira \\
\hline Paulo Manuel Pêgo Fernandes & São Paulo Medical Journal \\
\hline Regina Helena Garcia Martins & Brazilian Journal of Otorhinolaryngology \\
\hline Renato Soibelmann Procianoy & Jornal de Pediatria \\
\hline Ricardo César Pinto Antunes & Revista da Sociedade Brasileira de Cancerologia \\
\hline Ricardo Fuller & Revista Brasileira de Reumatologia \\
\hline Ricardo Guilherme Viebig & Arquivos de Gastroenterologia \\
\hline Ricardo Nitrini & Dementia \& Neuropsychologia \\
\hline Rogério Dedivitis & Revista Brasileira de Cirurgia Cabeça e Pescoço \\
\hline Ronaldo Damião & Urologia Contemporânea \\
\hline Rosângela Monteiro & Revista Brasileira de Cirurgia Cardiovascular \\
\hline Sergio Lianza & Revista Medicina de Reabilitação \\
\hline Sigmar de Mello Rode & Brazilian Oral Research \\
\hline Tarcisio E.P. Barros Filho & Acta Ortopedica Brasileira \\
\hline Wallace Chamon & Arquivos Brasileiros de Oftalmologia \\
\hline Winston Bonetti Yoshida & Jornal Vascular Brasileiro \\
\hline Zuher Handar & Revista Brasileira de Medicina do Trabalho \\
\hline
\end{tabular}

